\title{
Review
}

\section{Second nature: Rethinking the natural through politics}

\author{
Crina Archer, Laura Ephraim and Lida Maxwell (eds) \\ Fordham University Press, New York, 2013, £16.99/\$26.00, 216pp., \\ ISBN: 978-0823251421, £16.99/\$26.00
}

Contemporary Political Theory (2015) 14, e197-e200. doi:10.1057/cpt.2014.15;

published online 21 October 2014

The seven diverse essays drawn together in this book are united in their focus on the inescapable hybridity and mutually constitutive nature of the 'natural' world of material things and the 'political' world of conventions and social constructions. The 'second nature' approach developed through the book aims to veer away from two positions. First, by paying attention to the ongoing significance of nature, it looks to avoid approaches that 'denaturalize everything from justice to law to gender to nature itself' by 'revealing their conventional, cultural, politically constructed grounds' (p. 1). But in understanding nature as always already a second nature, shaped by human interpretations of and relations with it, the book also calls into question those environmental and liberal capability approaches that seek to 'recover some point of stable purchase that nature might still give us' (p. 3). The notion of second nature, in so doing, rejects ideas of a pure environment, untainted by polluting human practices, or an aspect of our humanity 'that is given prior to cultural production and thus could provide an unyielding point of fixity for politics' (p. 4). Against these positions, the contributors show, in different ways, that 'nature and politics were always already hybrid', mutually shaped through their agonistic relationship (p. 4). Contra green and capability theorists, there is no pure nature to which we can escape; even the pure, untainted green wilderness is a product of a 'deeply political project' (p. 15). Contra moves to denaturalize everything, materiality has effects on our social constructions.

The different chapters in the book all show that 'nature' is not a pure, untainted arena outside of politics that can be understood by technical or scientific experts in isolation, but is instead always already a 'second nature' inflected by culture and politics. This second nature can only be understood, as the subtitle indicates, through politics, and politics itself will involve interpretations of and relations with the 'natural' world. From this perspective, debates that might initially appear to favour forms of elite, technical understanding, be they debates on the appropriate ways to dispose of or use dead bodies (chapters by Laqueur, Honig), on the use of genetically

(C) 2015 Macmillan Publishers Ltd. 1470-8914 Contemporary Political Theory Vol. 14, 2, e197-e200 
modified seeds (editorial introduction), on the qualities of 'bare' humanity (chapter by Gündogdu) or on biotechnology (chapter by Biser) are inescapably political. In providing diverse analyses of these 'second natures', or 'assemblages' of what have sometimes been regarded separately as nature and politics, the book is a worthwhile read for those interested in new materialist political analysis.

Moreover, in demonstrating the political significance of readings of 'nature', the book also has a broader significance for a wide range of ethical and political debates concerning 'natural' or 'material' things. This significance can be seen in the emergent theme that develops through Thomas Laqueur's and Bonnie Honig's chapters concerned with the use of dead bodies. Through a detailed analysis of the cremationist movement in late nineteenth-century Britain, Thomas Laqueur demonstrates the movement's attempt to shift the terms of questions concerning the treatment of dead bodies away from a rooting in 'an almost two-millennia-old civilization based on Christian death rituals' (p. 60). Instead, such questions were to become 'a part of the question of nature, one part of the technical problem of disposal', with the expertise of 'sanitary engineers, doctors, and public health experts' to be used to ensure the hygienic disposal of decaying bodies (p. 50). However, this replacement of cultural and ethical understandings of dead bodies with a depoliticized and technical form of expertise, Laqueur argues, called on existing cultural values according to which 'the level and quality of civilization' was to be judged in terms of how the dead were treated (p. 59). Thus, what appears to be the replacement of politics by a non-political understanding of nature is demonstrated to retain cultural and political content.

Bonnie Honig's chapter calls into question the 'humanist binary' (p. 82) opened up by Laqueur's contrast between the cultural significance of dead bodies and the failed attempt to treat them as natural entities to be appropriately utilized and appropriately disposed of. Honig does so by exploring recent proposals that dead bodies be recycled to provide sustainable energy; proposals that show an unsettling 'complicity' between 'late capitalism's ceaseless demand for human productivity' and 'its supposed antagonist - environmentalism' (p. 63). These proposals initially seem to represent the 'end of humanism', where cultural and political commitments to dignity, understood in terms of 'the proper burial of the dead', are replaced by a narrow, technical understanding of how the dead are best put to productive and ecological use (p. 62). Honig's political rereading of the treatment of bodies is able to 'disrupt' this 'humanist binary of dignity versus use' (p. 82). Honig points to an AIDS activist's request that his dead body be put on the steps of the United States Food and Drug Administration to highlight and contest an unjust social order in which 'government disinterest in a public health emergency ... wiped out nearly two generations of gay men' (p. 64). For this activist, dignity is gained through his dead body being put to use as a symbol of criticism. These chapters both re-read nature politically by suggesting that purportedly 'natural' bodies are already second natures, inflected with political significance. In so doing, they highlight the political stakes

e198 @ 2015 Macmillan Publishers Ltd. 1470-8914 Contemporary Political Theory Vol. 14, 2, e197-e200 
that exist within debates on 'nature', and highlight some of the ethical and political avenues opened via a rethinking of the natural through politics.

The ethical and political significance of the second nature framework is explored throughout the diverse range of analyses that make up the remaining chapters of the book. Yves Winter provides a rereading of Machiavelli, suggesting that 'the topos of second nature fundamentally structures Machiavelli's view and understanding of the human' (p. 28). Ashley Biser focuses on how biotechnology 'challenges the distinction between nature and artifice' (p. 83) in order to offer a new reading of Arendt's distinction between nature and artifice. Christopher Buck's chapter focuses on environmental issues as a means to reorientate philosophical debates regarding immanence and transcendence in order to defend Adorno from some of his critics. Ayten Gündogdu's chapter discusses human rights as a second nature and, against Agamben, explores the potentialities within human rights. These diverse analyses are interesting and do show the diverse areas in which 'the framework of second nature opens up an exciting site of political contest' (p. 25).

However, in light of the possibilities the second nature framework opens up for a new thinking of assemblages of nature, culture and politics, it is a shame that the book does not do more to directly address debates in environmental politics. The editorial introduction highlights the potential relevance of the framework to environmental debates regarding deliberative mechanisms that cultivate greater environmental concern. The contributions, though, do not explicitly demonstrate the significance of an understanding of 'second nature' for Green politics. Despite having some focus on environmental issues, Buck's focus on philosophical debates surrounding immanence and transcendence means that his chapter only points suggestively to the 'emancipatory' possibilities of thinking of a future for the environment outside of 'the never-ending pursuit of surplus value' (p. 148). While Gündogdu's chapter has the most explicit political content, it does not relate directly to environmental politics. As a result, these attempts to reorient philosophical debates do not directly offer the 'meaningful political guideposts' helping us face the immediate environmental threats suggested in the editors' introduction (p. 2).

A further problem with the second nature approach is highlighted by Jane Bennett's chapter, with which the book closes. To constitute a position that is distinct in its political implications from approaches that denaturalize everything, explorations of second nature must accord some significance to what Bennett calls the 'force of things' (p. 150). They must demonstrate that nature, rather than being endlessly malleable to the second natures produced through hybrid entanglements, is 'a lively actor in the world' (p. 149) with its own resilience and affectivity. However, only Bennett's chapter, which begins by calling into question 'the discourse of second nature' on the basis that it 'tends still to give primacy to ... human actors', explicitly engages with the force things have in contributing to hybrid naturalpolitical assemblages (p. 151). Bennett's chapter thus seems to go further than the 'second nature' framework in showing that materiality has an 'active presence' and 
'amazing power' (p. 152). Nonetheless, the fact that the book ends with the development of a new materialist perspective serves once more to demonstrate the value of the book for those interested in new materialist analysis, with the book showing how this distinctive perspective emerged from attempts to rethink the natural through politics.

Robin Dunford

University of Exeter, Exeter, UK

e200 () 2015 Macmillan Publishers Ltd. 1470-8914 Contemporary Political Theory Vol. 14, 2, e197-e200 